\title{
The prospective EFL teachers' impressions towards teaching styles: Foresights for their professions*
}

\author{
Ayfer Su-Bergil ${ }^{\mathrm{a}} \uparrow$ (iD), Ayşegül Erçevik ${ }^{\mathrm{b}}$ \\ ${ }^{a}$ Amasya University, Faculty of Education, Amasya, 05100, Turkey \\ ${ }^{b}$ Amasya University, Faculty of Education, Amasya, 05100, Turkey
}

\section{APA Citation:}

Su-Bergil, A., \& Erçevik, A. (2019). The prospective EFL teachers' impressions towards teaching styles: Foresights for their professions. Journal of Language and Linguistic Studies, 15(4), 1236-1251.

Submission Date:09/07/2019

Acceptance Date:06/11/2019

\begin{abstract}
The expanding belief based on many researches and evidences across the world is that the teachers' quality goes beyond the requirements of what the educational system provide for the whole stakeholders. In this sense, the promising quantity of prospective English as a Foreign Language (EFL) deserves to maintain up to date and comprehensive knowledge of pedagogy which would furnish them with high standard teaching skills and competences. Therefore, this study focuses on delving into the teaching styles of 34 prospective EFL teachers, which will present the pedagogical knowledge of their teaching styles and how they will perform them when they are in action. For this purpose, Grasha's teaching style inventory consisting of 40 items in a 5-point likert-type format was used to collect data. The descriptive statistics in addition to the parametric calculations promoting information related to the prospective EFL teachers in specific and general to attain the personal teaching style preferences of them and a prevailing sight about the disposition of the target prospective EFL teachers of Amasya University are taken into account in the data analysis process. The analysis process announces that the courses aimed to provide the prospective EFL teachers with professionalism should be elaborated and handled meticulously during their faculty education. Furthermore, the association between the teaching style preferences that prospective EFL teachers desire to teach and their real teaching style(s) they exhibit and declare professionally should be regarded by policy makers in the employment process of teachers.
\end{abstract}

(C) 2019 JLLS and the Authors - Published by JLLS.

Keywords: teaching English as a foreign language; teaching styles; Grasha's teaching style

\section{Introduction}

When teaching is concerned as a profession, this belief addresses the demand of reaching the great aspects necessitate to maintain contemporary new skills and competences. Prospective English as a

*The findings of this study were obtained from the scientific research project funding by the Scientific Research Commission of Amasya University and partially presented in the $8^{\text {th }}$ International Conference of Strategic Research on Scientific Studies and Education in 11-13 May 2018 - Vienna University - Vienna/Austria.

${ }^{\dagger}$ Corresponding author. Tel.: +0-358-211-5046

E-mail address: ayfer_su@yahoo.com 
foreign language (EFL) teachers, who shares an important quantity among the teachers community or population, desire to develop themselves professionally by paying attention to acquiring good pedagogically driven knowledge which is what the authorities expect the teachers to have in order to reach the students' achievement in foreign language learning requiring the teachers to be proficient with advanced foreign language skills (Köksal \& Ulum, 2019, p. 485). Moreover, this pedagogy highlights that it is essential for EFL prospective teachers to develop an awareness of the importance of how and to what extent to use the teaching styles in teaching English as professional teachers.

Across the world, the belief that the quality of the education depends mainly on the teachers has been expanding. In accordance with this belief, there have been many researches and proofs, which focus on the significance of the teachers by claiming that the functions of them go further than what the educational system requires from the stakeholders (Önal \& Alagözlü, 2018). Thus, the key point reached today pays attention to the "teaching as a craft" rather than "teaching as knowledge".

Teaching as a craft has long seen the professionalization as a basis for not only hope but also frustration for the teachers. Thus, especially the primary and secondary education have been accepted as requiring special knowledge and skills in order to take place and stand in the same positions of traditional professions such as law and medicine. For these reasons, the higher education is regarded to furnish the prospective teachers with real classroom experiences, the abilities to plan and teach their courses parallel to the education system and demonstrate the required and appropriate behaviours (Sarıçoban, 2016, p. 167) addressing the critical changes and standards for the language teachers' roles with respect to the practices of language teaching process (Yüce, 2019; Arıkan, 2016).

At this point, when style is mentioned in teaching it is well known that it refers more than onedimensional aspects and interest of manner in order to develop positive reactions. By the way, prevalent and pervasive characteristics are viewed as the best ways playing crucial roles in different conditions of professional teaching. Moreover, the personal characteristics and qualities of the teachers monitor the way of the instructional ways in terms of how to select and apply them for the teaching processes (Kartal \& Başol, 2019). Thus, teaching styles turn into a responsible and comprehensive component of transferring the contents of the teaching discipline.

\subsection{Teaching style models}

Teaching Style Models has been studied by many researchers in the review of literature between 1972 to 2004. Broudy (1972) referred to the teaching styles by defining the three teaching modes of didactics, heuristics and philetics. Broostrom (1975) developed a teaching style inventory in which the styles were specified in terms of behaviorist, structuralist, functionalist and humanist aspects. Witkin, Fisher and Fisher, Dunn and Dunn (1979) tried to find out the effect of cognitive styles on academic performances, the relation between the teaching and learning styles of the students, and the influence of personality on teaching and learning styles. Butler (1984) focused on theoretical and practical aspects of teaching and learning styles. Mosston and Ashworth (1986) described the process of teaching styles by declaring the minimum and maximum independence of decision-making process. Joyce and Weil (1986) proposed models of teaching styles namely direct/interactive, inquiry, learning cycle, synectics, imagineering, integrative, cooperative learning, and person-centered models referring to the theories of Behavioral Psychology, Cognitive Psychology, and Social and Humanistic Psychology. Heimlich and VanTilburg (1990) searched for the development of adult teaching styles. Brekelmans, Levy and Rodrigez (1993) paid attention to the typology of teacher communication in terms of styles. Dunn and Dunn (1993) aimed to define the appropriate teaching styles in accordance with the learning styles of the students. Reinsmith (1994) concentrated the belief that the teaching style is the collection teachers' existence and characteristics, which are expected to be in harmony with the students' features. Quirk 
(1994) classified the teaching styles into four distinctive categories named as assertive, suggestive, collaborative, and facilitative which the teachers may ascribe one or some of them during their teaching process. Levine (1998) intended to find out applicable ways for mathematic teaching decreasing the anxiety levels of the students, which underline importance of teaching styles not only for teaching but also for the learning process of the students. Evans (2004) thought that the relationship between the cognitive style and teaching was underestimated and thus, determined to highlight the importance of cognitive styles of student teachers largely in order to help them develop their own predominant teaching styles. Although, the contributions of above-mentioned researches cannot be disregarded, the current study would reflect the findings involving the Grasha's (1996) teaching style since the natural tendency of the researchers conducting the whole part of the research have comprehensive and detailed belief of the addressed teaching style model.

\subsection{Grasha's teaching style}

According to the observations and interviews conducted in many researches, teachers share common features of Grasha's Model dealing with the teaching styles (Grasha, 1996). In addition to this, however the recent studies pay attention to the constructive ways of teaching fundamentally, the teaching styles oriented by the teachers are realized predominantly rather than the teaching styles oriented by the students. On the ground that traditional ways of teaching were utilized, and the teachers preference was to use and apply the teaching styles oriented by themselves in their own classroom settings extensively, this study aimed to focus on Grasha's teaching style even at the pre-service ELT education programs.

In the following section, the Grasha's teaching styles are explained in summary in terms of teachers, the features of teachers, advantages and disadvantages of related styles. To starting with the expert teaching style, it could be said that this style requires the teachers having knowledge and expertise about the possible needs the students may desire to learn. This teaching style makes the teachers maintain the expert status among their students in a way that they can display the accurate and comprehensive knowledge. By the way, the teachers enforce the students for the challenging situations and desire them to develop their competence. As an expert, the teachers have the roles of transmitting information, and expect the students to learn what they received and utilize the information they are transmitted. The teachers' expert teaching styles can be expected as one of the advantages in that they have accurate and comprehensive knowledge, skills and information about the target scope they aim to teach the students. As one of the disadvantages, it can be asserted that the overuse expert style may constrain the students who do not have enough or detailed knowledge about the target topic they are expected to learn. Moreover, the presentation of the knowledge or information may not always interest them at all.

Formal authority teaching style requires the teachers having positions among the students because they are perceived as a member of school or faculty who contribute to the students' teaching and learning processes by providing them positive and negative feedback. The teachers arrange concrete learning situations by establishing learning goals, expectations and principles for their learners. By this way, the learners may motivate on ideal, correct and typical methods of learning. One of the advantages this teaching style has is to be focused on definite expectations and reasonable methods during the process of teaching and learning. On the contrary, huge efforts required by this teaching style may result in common, fixed and inflexible process for the students or learners during the management of their involvement, which could be accepted as a disadvantage for this teaching style.

Personal model teaching style provides the learners with personal examples in that teachers or professors are seen as prototypes when the students or learners are expected to think, behave about something and in this process, the teachers need to inspect, manage and conduct the learners by demonstrating what and how to do in these contexts. In doing so, personal model teachers motivate their 
learners for observing, imitating or mirroring the methods and approaches their teachers provide them. The requirements of observation and imitation for the learners are the advantages of this teaching style model. On the other hand, the teachers or the professors strong beliefs that their approach or methods are the best way for their students, and the learners feeling inadequate in the situations where they cannot meet their expectations or apply the methods they are provided with or observed are significant disadvantages of this teaching styles which the implementers need to take into consideration.

In the facilitator teaching style, the individual quality takes priority in the teacher-student interactions. The options, questions and opportunities given by the teachers serve as guidelines and lead the learners during their learning situations. In this teaching style, the learners are expected to develop their own criteria in order to learn something. The teachers concentrate the goal of the whole classroom and by this way; the individual capacity and responsibility of the learners can be initiated with the possible encouragement and support the students may need during their learning. The flexibility of the individuals in this teaching style focusing on the needs and goals of the learners and by this way the learners' exploration for appropriate alternatives and opportunities for their actions are among the prior advantages. In this style, the teachers and the learners may need more time which could be timeconsuming for them. In addition to this, the possibility of the learners' need of some or more direct methods or approaches especially when they do not feel comfortable themselves in their learning process is among the disadvantages of this teaching style.

Delegator teaching style aims to develop the learners' capacity in order to furnish them with autonomous features. In this teaching style, the learners are expected to work on their projects independently as an autonomous member of their team. When the learners need, they can easily apply their teachers or professors for their demands or as a source of information. As an advantage, in this teaching style the learners have the opportunity of being independent learners because they are expected to perceive themselves, however the teachers may sometimes confuse about the readiness of their students for their independent responsibilities and being confronted with the autonomous requirements may also cause the learners to feel and become anxious for their current or further works. Thus, as a disadvantage it should be kept into consideration that the learners may not have the desired capacity to fulfil their autonomous responsibilities and they may need close supervision for their anxious feelings in order to cope with them and renew themselves in their learning situations. Based on Grasha's teaching style framework and the effort to contribute to the review of literature mentioned above, this research explores the answers of the following questions:

$>$ What are the perceptions of prospective EFL teachers about their teaching styles?

$>$ What are the teaching style inclinations of prospective EFL teachers?

$>$ Are the teaching styles perceptions and inclinations of prospective EFL teachers consistent with each other?

How do the teaching style preferences range in terms of gender among prospective EFL teachers?

\section{Method}

Since the current study aims to reach a snapshot investigation about the prospective EFL teachers' impressions towards their own teaching styles, quantitative research involving descriptive survey model was used directly in the current study. In this aspect, quantitative research can be explained as a method of research, which relies on measuring the variables with a numerical system for the purpose of analyzing the measurements of several statistical models and addressing the relations and associations among the variables included in the studies. The primary goal of compiling the quantitative data is to 
figure out, illustrate, and predict the nature of a phenomenon, particularly through creating foundations with the development of models and theories. These are the reasons explaining that quantitative research techniques may include experiments and surveys (Arikan, 2013, p. 27).

\subsection{Participants}

Voluntary participation of 34 prospective English as foreign teachers studying at the department of English Language Education at Amasya University during the fall semester of 2017-2018 academic year was the prior requirement of this study. Due to the fact that there were limited numbers of students registered in this department, the whole participants meeting the desired qualifications one of which is taking the course of "Teaching English to Young Learners" for the research were included into without any selection. Hence, the convenience sampling method is selected due to the availability and willingness of the participants to take part into the research. Although the number of the participants included in this study is limited and may not be representative to reach a comprehensive generalization concluded from the collected data, which also one of the disadvantages of using non-probability sampling methods, it would be useful to take into consideration that the number of the participants is acceptable for quantitative research. Moreover, because of the invalid and unsatisfied data, 2 of the participants were excluded from the study and the collected data related to them were not included to the calculation process of the data.

Table 1. The age distribution of participants

\begin{tabular}{lllll}
\hline Age & f & Percent & Valid Percent & Cumulative Percent \\
\hline 20.00 & 5 & 14.7 & 14.7 & 14.7 \\
21.00 & 19 & 55.9 & 55.9 & 70.6 \\
22.00 & 7 & 20.6 & 20.6 & 91.2 \\
23.00 & 1 & 2.9 & 2.9 & 94.1 \\
33.00 & 1 & 2.9 & 2.9 & 97.1 \\
41.00 & 1 & 2.9 & 2.9 & 100.0 \\
Total & 34 & 100.0 & 100.0 & \\
\hline
\end{tabular}

Table 1 displays the age distribution of the participants included in the study. As the table reflects, 19 of the students who are 21 years old represent $55.9 \%$ of the total population. This is followed by the 22 and 20 years old students with the frequency of 7 and 5 representing the $20.6 \%$ and 14.7 of the sample. By the way, the other participants being at the age of 23,33, and 44 shares the same frequency with the same percentage of 2.9 , which points almost the homogeneity of the sample. 
Table 2. The gender distribution of participants

\begin{tabular}{llllll}
\hline Gender & Frequency & Percent & Valid Percent & Cumulative Percent \\
\hline \multirow{2}{*}{ Valid } & Male & 9 & 26.5 & 26.5 & 26.5 \\
& Female & 25 & 73.5 & 73.5 & 100.0 \\
& Total & 34 & 100.0 & 100.0 & \\
\hline
\end{tabular}

Regarding the gender variable, Table 2 sums up the reality that most of the ELT departments consist of female students as this study defines 25 participants out of 34 with the percentage of 73.5 while 9 of them constitute $26.5 \%$ of the total participants included in this study.

Table 3. The participants' desire to teach

\begin{tabular}{lcccc}
\hline Level of Teaching & Frequency & Percent & Valid Percent & Cumulative Percent \\
\hline Primary School & 10 & 29.4 & 29.4 & 29.4 \\
Secondary School & 10 & 29.4 & 29.4 & 58.8 \\
High School & 8 & 23.5 & 23.5 & 82.4 \\
University & 6 & 17.6 & 17.6 & 100.0 \\
Total & 34 & 100.0 & 100.0 & \\
\hline
\end{tabular}

Table 3 illustrates the levels where the participants' desire to teach. For this purpose, the participants are given the primary, secondary, high school, and university options. As seen, 20 participants out of 34 desire to teach at the primary and secondary level which meet $58.8 \%$ of all. 8 and 6 of them prefer to teach at high schools and universities consisting of 23.5 and $17.6 \%$ of the sample, which address the importance and the influence of Teaching English to, which address the importance and the influence of Teaching English to Young Learners course the ELT student are required to take during their faculty of education.

\subsection{Data collection procedures}

In this study, data were collected through Grasha's Teaching Style Inventory consisting of 40 items in the fall semester of 2017-2018 academic year. Grasha' Teaching Style Inventory was applied to the $3^{\text {rd }}$ Grade English as a Foreign Language learners who take Teaching English to Young Learners Course in which the participants are expected to experience microteaching process. This course is accepted as one of the most microteaching related among the compulsory and elective courses included in English Language Teaching Departments under the control of the Council of Higher Education in Turkey. Accordingly, the participants are required to carry out two microteaching practices one of which is about the first day first lesson as an introduction and how to use multiple intelligence theory to develop the listening or speaking skills of the young learners. The microteachings are preconditions for the current study as the researchers should be aware that the participants are familiar with the teaching process even though they take place in unnatural scenarios so that they are able to get impression on their own teaching styles. Furthermore, the items were scaled as "1=strongly disagree", "2=moderately disagree", 
"3=undecided", "4=moderately agree" and "5=strongly agree" following the background and demographic information required by the participants (Grasha, 1996). During the data collection process, there was time limitation of 45 minutes for the participants to complete the inventory. All the participants were asked to complete the inventory sincerely and cordially in addition to their voluntary participation.

Table 4. The items of each teaching style included the inventory

\begin{tabular}{lllll}
\hline Expert & Formal Authority & Personal Model & Facilitator & Delegator \\
\hline 1. & 2. & 3. & 4. & 5. \\
6. & 7. & 8. & 9. & 10. \\
11. & 12. & 13. & 14. & 15. \\
16. & 17. & 18. & 19. & 20. \\
21. & 22. & 23. & 24. & 25. \\
26. & 27. & 28. & 29. & 30. \\
31. & 32. & 33. & 34. & 35. \\
36. & 37. & 38. & 39. & 40. \\
\hline
\end{tabular}

In order to group the sub-categories of the teaching styles mentioned above, the arithmetic means of the scores obtained from the teaching style scale is based on as an assessment criterion. Depending on the severity, the scores based on the collected data of the inventory are placed into the classes as:

Table 5. Severity levels of teaching styles

\begin{tabular}{lccc}
\hline Teaching Style & Low & Moderate & High \\
\hline Expert & $1-2$ & $2.1-3.1$ & $3.2-5$ \\
Formal authority & $1-2.8$ & $2.9-3.9$ & $4-5$ \\
Personal model & $1-3.2$ & $3.3-4.1$ & $4.2-5$ \\
Facilitator & $1-3$ & $3.1-4$ & $4.1-5$ \\
Delegator & $1-2.5$ & $2.6-3.7$ & $3.8-5$ \\
\hline
\end{tabular}

Table 5 shows the severity levels of the teaching styles for the current study. According to this table, for expert teaching style the scores between 1-2, 2.1-3.1 and 3.2-5 are separately accepted as low, moderate and high. For formal authority the scores between 1-2.8, 2.9-3.9 and 4-5; for personal model the scores of 1-3.2, 3.3-4.1 and 4.2-5 are specified as low, moderate and high while for facilitator teaching style 1-3, 3.1-4, and 4.1-5; for delegator teaching style 1-2.5, 2.6-3.7 and 3.8-5 are defined as low, moderate and high. These severity levels are adopted to the following findings of the study in order to designate the teaching styles of the participants appropriately.

Afterwards, the reliability levels of each teaching style covered in the inventory were calculated according to the Cronbach Alpha. The reliability levels for each teaching style hold by the inventory are given in the following table: 
Table 6. The reliability levels of each teaching style of the inventory

\begin{tabular}{lccc}
\hline Part of the Inventory & $\begin{array}{c}\text { Number of Items } \\
\text { Inventory }\end{array}$ & $\begin{array}{c}\text { Grasha's Cronbach's } \\
\text { Alpha Levels }\end{array}$ & $\begin{array}{c}\text { Cronbach's Alpha Levels } \\
\text { of the Current Study }\end{array}$ \\
Expert & 80 & .85 & .93 \\
Formal Authority & 8 & .75 & .84 \\
Personal Model & 8 & .80 & .56 \\
Facilitator & 8 & .66 & .69 \\
Delegator & 8 & .84 & .68 \\
\hline
\end{tabular}

Table 6 presents the reliability levels belonging to the original study applied by Grasha (1996) and calculated for this study. According to Cronbach Alpha levels of each teaching style, it is seen that the results demonstrate that the scale enjoys the required reliability perfectly for the whole inventory in general beside the expert, personal model, facilitator and delegator teaching styles in specific. To be honest, the data collection procedure for the formal authority teaching style could be repeated with more participants or should be revised in the further studies. However, in this study the formal authority teaching style was not excluded in order to be faithful to the original inventory, which could be accepted as other limitations for some researchers.

\subsection{Data analysis}

The obtained data were analyzed and interpreted using the SPSS 20.00 software program for social sciences. Descriptive analysis was conducted to the dimensions of the scale, gender and age distributions of the participants, and severities of the teaching styles by extracting percentages and frequencies. The exploratory classifications to illustrate the relation of the scale with the perceived answers of the participants were presented. Meanwhile, non-parametric methods of Mann Whitney U Test was used in order to determine whether the dimensions of the scale differ significantly in terms of gender distribution since the number of males and females participated in the study is $\mathrm{N}<30$. In addition to this, Pearson's Correlation Coefficient statistics was applied to find out the relations between the dimensions of Teaching Style Inventory.

\section{Findings and Discussions}

The findings of the study associated with the answers of the assigned research questions are presented in the tables below with related discussions in line with the previous studies. 
Table 7. The perception of prospective EFL teachers about their teaching styles

\begin{tabular}{lcccc}
\hline Determined Teaching Style & Frequency & Percent & Valid Percent & Cumulative Percent \\
\hline Expert & 4 & 11.8 & 11.8 & 11.8 \\
Formal authority & 5 & 14.7 & 14.7 & 26.5 \\
Personal model & 11 & 32.4 & 32.4 & 58.8 \\
Facilitator & 12 & 35.3 & 35.3 & 94.1 \\
Delegator & 2 & 5.9 & 5.9 & 100.0 \\
Total & 34 & 100.0 & 100.0 & \\
\hline
\end{tabular}

According to the findings of the determined teaching style of the participants, it is concluded that personal model and facilitator teaching styles with the frequencies of 11 and 12 representing 32.4 and $35.3 \%$ of the sample appeal the participants mostly. Delegator and expert teaching styles with 2 and 4 frequencies with 5.9 and 11.8 percentages appeal the participants at least. In this part of the inventory, it was aimed to have the participant choose their teaching styles by giving them only the names of those styles. Later, as presented in the following parts when they were introduced the items of the inventory and it was aimed to observe whether their teaching styles are different from what they determined. The learners or the student teachers may reflect different attitudes to the teaching styles they would use in their professional lives from their learning styles. Thus, here without the items of the inventory they might perceive the teaching styles by relating them with their own learning styles. This is in line with what Grosse (1986) stated by declaring that teaching styles cannot be associated with the learning styles assumed as generally.

Table 8. The teaching style of prospective teachers related to the severity

\begin{tabular}{lllllllllll}
\hline & \multicolumn{2}{c}{ Expert } & \multicolumn{2}{c}{ Formal Authority } & \multicolumn{2}{c}{ Personal Model } & \multicolumn{2}{l}{ Facilitator } & \multicolumn{2}{c}{ Delegator } \\
\hline & $\mathrm{f}$ & $\%$ & $\mathrm{f}$ & $\%$ & $\mathrm{f}$ & $\%$ & $\mathrm{f}$ & $\%$ & $\mathrm{f}$ & $\%$ \\
\hline Low & 1 & 2.9 & 3 & 8.8 & 1 & 2.9 & 1 & 2.9 & 1 & 2.9 \\
Moderate & 2 & 5.9 & 21 & 61.8 & 19 & 55.9 & 11 & 32.4 & 11 & 32.4 \\
High & 31 & 91.2 & 10 & 29.4 & 14 & 41.2 & 22 & 64.7 & 22 & 64.7 \\
\hline
\end{tabular}

Table 8 shares the frequencies and percentages of teaching styles in that 31 EFL learners with the percentage of 91.2 have high level expert teaching style while 2 and 1 of them consisting 5.9 and $2.9 \%$ of the sample have moderate and low level of this teaching style. On the other hand, 21 participants representing 61.8 of the sample have moderate formal authority teaching style though 10 and 3 of them with the percentages of 29.4 and 8.8 have high and low level of the target teaching style. 19 and 14 participants with 55.9 and $41.2 \%$ have moderate and high-level teaching style, however, 1 of them with $2.9 \%$ has the same teaching style. Furthermore, 22 and 11 of the participants have high and moderate teaching styles with 64.7 and 32.4 whereas 1 of them with $2.9 \%$ has low facilitator teaching style. Finally, 22 and 11 of the participants with 64.7 and $32.4 \%$ have delegator teaching style as well as 1 of them has low teaching style with $2.9 \%$. According to these findings, it is revealed that most of the students studying at English Language Teaching Department of Amasya University have facilitator and delegator teaching styles which would direct and guide them during their real life teaching process when they finish their faculty of education, and this can be accepted as hopeful for the future of English as a Foreign Language Teachers in Turkey. 
Table 9. Relation between the perceived and analyzed teaching styles

\begin{tabular}{|c|c|c|c|c|c|c|}
\hline Participants & Perceived Style & Expert & Formal Authority & $\begin{array}{l}\text { Personal } \\
\text { Model }\end{array}$ & Facilitator & Delegator \\
\hline 1 & Delegator & High & Average & Average & Average & High \\
\hline 2 & Facilitator & High & Average & Average & Average & High \\
\hline 3 & Facilitator & High & High & High & High & High \\
\hline 4 & Facilitator & High & High & High & High & High \\
\hline 5 & Facilitator & High & Average & Average & High & Average \\
\hline 6 & Facilitator & High & Average & Average & Average & Average \\
\hline 7 & Expert & High & High & High & High & High \\
\hline 8 & Facilitator & High & Average & Average & High & High \\
\hline 9 & Delegator & High & Average & High & High & High \\
\hline 10 & Formal Authority & High & Average & Average & High & High \\
\hline 11 & Formal Authority & High & Average & Average & Average & High \\
\hline 12 & Personal model & High & High & High & Average & High \\
\hline 13 & Expert & High & Average & Average & High & Average \\
\hline 14 & Personal model & High & Average & Average & Average & Average \\
\hline 15 & Personal model & High & Average & High & High & High \\
\hline 16 & Formal Authority & High & Average & High & High & High \\
\hline 17 & Personal model & High & Average & Average & High & High \\
\hline 18 & Formal Authority & High & Average & Average & Average & Average \\
\hline 19 & Expert & Average & Low & Average & Average & Average \\
\hline 20 & Personal model & High & Average & Average & Average & Average \\
\hline 21 & Facilitator & High & Average & Average & High & Average \\
\hline 22 & Personal model & Low & Low & Low & Low & Low \\
\hline 23 & Facilitator & High & Average & Average & High & High \\
\hline 24 & Personal model & High & Average & High & High & High \\
\hline 25 & Personal model & High & High & High & High & High \\
\hline 26 & Formal Authority & Average & Average & Average & Average & Average \\
\hline 27 & Facilitator & High & High & High & High & High \\
\hline 28 & Personal model & High & High & High & High & High \\
\hline 29 & Facilitator & High & High & High & High & High \\
\hline 30 & Facilitator & High & Average & Average & High & High \\
\hline 31 & Facilitator & High & Average & High & High & High \\
\hline 32 & Expert & High & High & Average & High & Average \\
\hline 33 & Personal model & High & Low & Average & Average & Average \\
\hline 34 & Personal model & High & High & High & High & High \\
\hline
\end{tabular}

Table 9 describes the perceived teaching styles the participants are expected to choose before the items of the inventory and shows how their calculated styles are according to the inventory. In this sense, this table compares the perceived or preferred teaching styles of the participants and their own teaching styles determined via Grasha's Teaching Style Inventory. Moreover, the table reflects that the prospective or student teachers of English as a Foreign Language may have all of these teaching styles in different degrees or at the same level depending on the personal characteristics or preference of the teachers. By the way, as highlighted in the table, the determined teaching styles of 13 participants out of 34 representing $38.2 \%$ of the sample do not show relation to their real teaching styles in terms of the specified levels of the teaching styles. More importantly, the determined teaching styles of 21 
participants out of 34 representing $61.8 \%$ of the sample are in accordance with the analyzed teaching styles of the applied inventory in this study. Thus, as the classroom interaction takes priority especially for the field of reflective teacher development in the English Language Teaching, not only the in-service teachers but also during the faculty of education the teacher candidates should have conscious about their classroom manners and the influence of them on learners (Yeşilbursa, 2017).

Table 10. The teaching styles profile of $3^{\text {rd }}$ grade students according to Grasha's inventory

\begin{tabular}{llcccc}
\hline \multicolumn{5}{c}{ Teaching Styles } \\
\hline \multirow{3}{*}{ Mean } & Expert & Formal authority & Personal model & Facilitator & Delegator \\
Degree & 3.94 & 3.67 & 3.98 & 4.12 & 3.87 \\
\cline { 2 - 6 } & High & Moderate & Moderate & High & High \\
\hline
\end{tabular}

Table 10 demonstrates the mean values and the degrees of each teaching styles related to the severity levels of them. Since, the mean values do not decide low, moderate or high levels of the teaching styles on their own, the severity of them plays a crucial role in this aspect. For instance, facilitator teaching style with the mean value of 4.12 has the high position such as the delegator and expert teaching styles with the mean values of 3.87 and 3.94. Although personal model and formal authority teaching styles have the moderate positions with the mean values of 3.98 and 3.67.

Table 11. Pearson correlation results for teaching styles

\begin{tabular}{lccccc}
\hline & Expert & Formal Authority & Personal Model & Facilitator & Delegator \\
\hline Expert & & & & & \\
Formal Authority & $.70(* *)$ & & & & \\
Personal Model & $.78(* *)$ & $.63(* *)$ & $.87(* *)$ & & \\
Facilitator & $.79(* *)$ & $.59(* *)$ & $.86(* *)$ & $.88(* *)$ & \\
Delegator & $.79(* *)$ & $.63(* *)$ & 3.99 & 4.13 & 3.88 \\
Mean & 3.94 & 3.67 & .49 & .41 & .46 \\
S.d & .58 & .47 & & & \\
$* * p<0.01$. & & & &
\end{tabular}

According to one of the parametric statistical procedure named as Pearson Correlation results, the correlation levels indicating the mean values of each teaching style section of the inventory fit into the significance at the 0.01 level. More interestingly, at the significance level of 0.01 , the table informs that each teaching style has high positive correlation with one another in different degrees. Regarding the high $( \pm 0.50$ and \pm 1$)$, moderate $( \pm 0.30$ and \pm 0.49$)$, and low degrees $( \pm .29)$ of correlation (Cohen, 1992), it is clear that expert teaching style has the highest positive correlation with the delegator teaching style $(r(32)=.79, p<.01)$ while the mentioned teaching style has the lowest high positive correlation with the formal authority teaching style $(r(32)=.70, p<.01)$. The Formal authority has the highest positive correlation with the delegator teaching style $(r(32)=.63, p<.01)$ but the lowest high positive correlation with the facilitator teaching style $(r(32)=.59, p<.01)$. However, the personal model teaching style has the high positive correlation with facilitator $(r(32)=.87, p<.01)$ and delegator $(r(32)=.86, p<.01)$ teaching styles. Finally, the facilitator teaching style has the high positive correlation level $(r(32)=.88$, $p<.01)$ with the delegator teaching style. As Grasha (1994) states the investigation of teaching styles may show the suggestion that there may be a blended variety of styles in the college or faculty classrooms. This is what Reinsmith (1992) proposes by claiming that the faculty students may not able 
to discover the teaching styles on their own but they can inherit the styles from whom they are affected because it is the prevalent aspect of faculty education and they are not isolated from the qualities of the teachers or professors surrounding them.

Table 12. Mann Whitney $U$ test results of teaching styles according to the gender

\begin{tabular}{llllllll}
\hline Teaching Styles & Gender & $\mathrm{N}$ & M.R & SR & $U$ & $z$ & $p$ \\
\hline \multirow{2}{*}{ Expert } & Male & 9 & 12.28 & 110.50 & \multirow{2}{*}{65.50} & -1.85 & \multirow{2}{*}{.064} \\
& Female & 25 & 19.38 & 484.50 & & & \\
\hline \multirow{2}{*}{ Formal Authority } & Male & 9 & 9.28 & 83.50 & \multirow{2}{*}{38.50} & -2.90 & \multirow{2}{*}{$.004 * *$} \\
& Female & 25 & 20.46 & 511.50 & & \\
\hline \multirow{2}{*}{ Personal Model } & Male & 9 & 7.22 & 65.00 & \multirow{2}{*}{20.00} & -3.63 & \multirow{2}{*}{$.000^{* * *}$} \\
& Female & 25 & 21.20 & 530.00 & & \\
\hline \multirow{2}{*}{ Facilitator } & Male & 9 & 8.17 & 73.50 & \multirow{2}{*}{28.50} & -3.33 & \multirow{2}{*}{$.001 * * *$} \\
\hline \multirow{2}{*}{ Delegator } & Female & 25 & 20.86 & 521.50 & & & \\
\hline$* * p<.01, * * * p<.001$ & Male & 9 & 8.28 & 74.50 & \multirow{2}{*}{29.50} & -3.26 & \multirow{2}{*}{$.001 * * *$} \\
\hline
\end{tabular}

Table 12 establishes the Mann Whitney U Test results of teaching styles according to the gender variable of the study. As reported by the above mentioned table there are significant difference between the mean values of male and female participants' teaching styles in that for formal authority $(U=38.50$, $z=-2.90, p<.01)$, personal model $(U=20.00, z=-3.63, p<.001)$, facilitator $(U=28.50, z=-3.33, p<.001)$, and delegator teaching styles $(U=29.50, z=-3.26, p<.001)$. However, for the expert teaching style in spite of the differences between the mean values of male and female participant, statistically there is no acceptable significance $(U=65.50, z=-1.85, p>.05)$. According to Starbuck (2003) there are many evidences for the gender differentiation in the selection of teaching styles. In particular, the findings of this part support the idea that student-based approaches included in the teaching styles are more likely to be utilized by the female teachers or teacher candidates while men are more likely to use lecture or technology-oriented methods in their own teaching styles. This finding agrees with the literature that female teachers and prospective teachers have general inclination to adopt the interactive methods and ways of teaching in their professions.

\section{Conclusions}

This research reflects the teaching style profiles and perceptions of prospective EFL teachers experiencing microteaching practices in Teaching English to Young Learners course. The results of the study also address that it is essential for prospective EFL teachers to develop an awareness of teaching styles not only for good young learners' classes but also for their future career as emphasized here for EFL teaching and learning process.

The findings of this research underlines that for an effective EFL atmosphere, the teachers should be aware of their teaching styles since they are the most important agents in the learning process (Amini, Samani \& Lotfi, 2012). By this way, they could be facilitators who will guide the learners by pacing and fine-tuning the procedures of the courses according to the learning styles of the learners.

The hope for overcoming the problem of coordination between the teaching methods and learning, it is known that there are many teachers who have conscious about the superiority of the methods they apply during their teaching process; however, some other teachers supply unconscious teaching materials for their students regardless of conducting a special way of teaching or method. Thus, in order to reach an effective education, the establishment of the special teaching methods referring to the styles 
what is here in this study focused on is crucial. The true and appropriate style is the one, which reveals what the learner has inherently and may change the way of education to some and great extent.

Nevertheless, the teacher trainers, educators and practitioners should pay attention that when they aim to develop the awareness of the student teachers' teaching styles, they have to be eager to utilize the practices of student-centre styles rather than teacher centered samples. Related to the findings of this study, the highest frequency of the teaching style belongs to the EXPERT ( $\mathrm{f}=31$ ), which displays us the urgency and necessity of the priority to move the student teachers as close as possible to the FACILITATOR and DELEGATOR teaching styles placing the learners at the centre of the teaching and learning process.

Furthermore, the results point out the importance of pedagogic purposes of the awareness of teaching styles in language teaching in the EFL classrooms. Thus, EFL teacher education programmes should link the study of teaching styles and learning styles in parallel since both of them have vital importance in giving and receiving the desired educational practices, which will reflect and serve as a kind of awareness and perception of the courses in terms of developmental process of prospective teachers (Fisher \& Fisher, 1979) in English Language Teaching Departments.

\section{Limitations and Suggestions}

As a result, it would be appropriate to state that this study was conducted under the limitations of:

$>$ The sample of the study consists of the prospective EFL teachers studying at the $3^{\text {rd }}$ grade at Amasya University, Turkey $(\mathrm{N}=34)$ because they have more microteaching practices related courses than the other grades before experiencing the practicum process at the $4^{\text {th }}$ grade.

$>$ The Teaching Style inventory proposed by Grasha consisting of 40 items was used in the data collection process of this research. The inventory is applied to the participants in its original scale range. Although the scale was mainly for the teachers who are in-service, there are studies in which the same scale was used to gain insights about the teaching styles of prospective teachers (Grosse, 1986; Ünal, 2017). Since the review of literature does not provide researchers with such a teaching style inventory for prospective teachers, this referred inventory is accepted as an applicable one supported by sample studies. The prospective teachers deserve to be investigated in terms of their teaching styles as they have teaching experiences to some extent during the teacher education process. In this aspect, the current study had vital importance to show the differences between what the prospective EFL teachers' perceived and actual teaching styles were. It also provided chance for them to improve their own teaching styles by giving feedback about their perceived teaching styles and giving information about their actual teaching style reached from the inventory with a seminar by the researchers of this study.

$>$ The data included in this research is gathered for Teaching English to Young Learners course which is enriched with microteaching practices aiming to develop the awareness of teaching styles in addition to Teaching Language Skills course which the prospective teachers are expected to take.

In this context, in order to generalize the findings, this small-scale study in which 34 prospective EFL teachers were included could be repeated with more participants of any other universities or countries with incorporating the control group as well. In addition, the similar study could be repeated with more groups regarding the prospective teachers' learning styles. Moreover, the findings of the prospective teachers' teaching styles could be taken into account with their achievements of courses 
correspondingly. These points may be the topics of other researches in that they would shed light on further academic and practical studies.

\section{References}

Amini, M., Samani, S., \& Lotfi, F. (2012). Reviewing Grasha teaching methods among faculty members of Shiraz medical school. Res. Dev. Med. Educ., 1(2), 37-43.

Arıkan, A. (2016). An examination of the EPOSTL's potential practical use in Turkey. Artuklu Human and Social Science Journal, 1(1), 76-80.

Arıkan, R. (2013). Araştırma yöntem ve teknikleri. (2 ${ }^{\text {nd }}$ Edition). Ankara: Nobel Yayıncılık

Brekelmans, M., Levy, J., \& Rodriguez, R. (1993). A typology of teacher communication style. In T. Wubbels and J. Levy (Eds.), Do you know what you look like? Interpersonal relationships in education (pp. 46 -55). London: The Falmer Press.

Büyüköztürk, Ş. (2006). Sosyal bilimler için veri analizi el kitabı (6 $6^{\text {th }}$ Edition). Ankara: PegemA Yayıncilik.

Cohen, J. (1992). Quantitative methods in psychology. Psychological Bulletin, 112(1), 155-159.

Creswell, J. W. (2014). Research design: Qualitative, quantitative and mixed methods approaches. Los Angeles: Sage.

Dunn, R. S., \& Dunn, K. J. (1979). Learning styles and teaching styles: Should they can they be matched?. Educational Leadership, 36(4), 238-244.

Dunn, R., \& Dunn, K. (1993). Teaching elementary students through their individual learning styles: Practical approaches for grades 3-6. Boston, USA: Allyn \& Bacon.

Evans, C. (2004). Exploring the relationship between cognitive style and teaching. Educational Psychology, 24(4), 509 - 531.

Evans, C., Harkins, M. J., \& Young, J. D. (2008). Exploring teaching styles and cognitive styles: evidence from school teachers in Canada. North American Journal of Psychology, 10(3), 567-582.

Farrell, T. S. C. (2015). Promoting teacher reflection in second language education: A framework for TESOL professionals. New York, NY: Routledge.

Fischer, B. B., \& Fischer, L. (1979). Styles in teaching and learning. Educational Leadership, 36(4), 245-254.

Grasha, A. F. (1983). Learning Styles: Journey from Greenwich observatory (1769) to the college classroom. Improving College and University Teaching Journal, 32(1), 46-53.

Grasha, A. F. (1994). A matter of style: The teacher as expert, formal authority, personal model, facilitator and delegator, College Teaching, 42(4), 12- 20.

Grasha, A. F. (1994). A special section discovering your best teaching styles. College Teaching, 42(4), $122-124$.

Grasha, A.F. (1996). Teaching with style: Enchancing learning by understanding teaching and learning styles. Pittsburg, PA: Alliance Publishers.

Grasha, A. F. (2002). The dynamics of one-on-one teaching. College Teaching, 50(4), 139-146. 
Grasha, A. F. (2003). Teaching with Style: The integration of teaching and learning styles in the classroom. Social Studies, 94(4), 179-187.

Grosse, C. U. (1986). Teaching and learning styles of ESL student teachers. JALT Journal, 8(1), 37-50.

Heimlich, J. E., \& Norland, E. (1994). Developing teaching style in adult education. San Francisco, America: Jossey-Bass.

Joyce, B., \& Weil, M. (1986). Models of teaching ( $3^{\text {rd }}$ ed.). Needham Heights, MA, Allyn \& Bacon.

Kartal, G., \& Başol, H. Ç. (2019). Generic teacher competencies and the English language teacher education program in Turkey. Novitas-ROYAL (Research on Youth and Language), 13(2), 134-155.

Köksal, D., \& Ulum, Ö. G. (2019). Pre-service EFL teachers' conceptions of language proficiency: entry and exit level qualifications. Journal of Language and Linguistic Studies, 15(2), 484-495. Doi: 10.17263/jlls.586144 Submission Date:02/10/2018

Levine, G. (1998). Changing anticipated mathematics teaching style and reducing anxiety for teaching mathematics among pre-service elementary school teachers. Educational Research Quarterly, 2(4), $37-46$.

Mosston, M., \& Ashworth, S. (1986). Teaching physical education ( $3^{\text {rd }}$ ed.). Columbus, OH: Merrill.

Önal, A., \& Alagözlü, N. (2018). A descriptive study on in-service English language teachers' perceptions of the European portfolio for student teachers of languages (EPOSTL) in Turkish setting. Journal of Language and Linguistic Studies, 14(3), 56-76.

Quirk, M. E. (1994). How to learn and teach in medical school: A learner-centered approach. New York, America: Charles C. Thomas Publishers.

Reinsmith, W. A. (1992). Archetypal forms in teaching: A continuum. Westport, Conn: Greenwood Press.

Reinsmith, W. A. (1994). Archetypal forms in teaching. College Teaching, 42(4), 131-136.

Sarıçoban, A. (2015). Metacognitive awareness of pre-service English language teachers in terms of various variables. Elsevier ScienceDirect Procedia Social and Behavioral Sciences.

Sarıçoban, A. (2016). Foreign language teaching practicum beliefs of student teachers. Journal of Language and Linguistic Studies, 12(1), 166-176.

Sarıçoban, A., \& Behjoo Bahram M. (2016). Academic self efficacy and prospective ELT teachers achievement. Journal of Language and Linguistic Studies, 12(1), 55-62.

Starbuck, G. H. (2003, April). College teaching styles by gender. Paper presented at Western Social Science Association Annual Meeting, Las Vegas, Nevada.

Ünal, M. (2017). Öğretmenlerin ve öğretmen adaylarının öğretme stillerinin farklı değişkenlere göre incelenmesi. Abant İzzet Baysal Üniversitesi Eğitim Fakültesi Dergisi, 17(2), 932-947.

Yeşilbursa, A. A. (2017). Reflections from the EFL classroom: Classroom interaction and reflective teacher development. Journal of Language Research, 1(1), 19-24.

Yüce, E. (2019). EPOSTL: Revisiting the roles of language teachers at a recently established ELT department. International Online Journal of Education and Teaching (IOJET), 6(1). 234-243. 


\title{
İngilizce öğretmen adaylarının öğretme stillerine yönelik izlenimleri: mesleklerine yönelik öngörüleri
}

\begin{abstract}
$\ddot{O} \mathbf{z}$
Dünyanın dört bir yanındaki araştırmalara ve kanıtlara dayanan görüş, öğretmenlerin kalitesinin, eğitim sisteminin tüm paydaşlara sağladıklarının gerekliliklerinin ötesine geçtiği yönündedir. Bu anlamda, gelecek vaat eden İngilizceyi bir yabancı dil olarak öğreten öğretmenlerin sayısı, onların yüksek standartlarda öğretim becerileri ve yeterlilikleri sağlayacak olan güncel ve kapsamlı pedagojik bilgi ile donanmalarını gerektirmektedir. Bu nedenle, bu çalışma 34 İngilizce öğretmen adayının pedagojik bilgilerini ortaya koyan öğretme stillerini ve eylem içerisinde bulunduklarında bunları nasıl kullandıklarını araştırmaya odaklanmaktadır. $\mathrm{Bu}$ amaçla, veri toplamak için Grasha'nın 5'li likert tipi formatta 40 maddeden oluşan öğretim stili envanteri kullanılmıştır. Veri analizi sürecinde Amasya Üniversitesinde öğrenim gören İngilizce öğretmen adaylarını genel ve özelde eğilimleri olan ve tercih ettikleri öğretim stillerinin belirlenmesine yönelik ele alınan parametrik hesaplamaların yanı sira betimsel hesaplamalara da yer verilmiştir. Analiz süreci, İngilizce öğretmen adaylarının profesyonelliğini sağlamayı amaçlayan derslerin, fakülte eğitimleri sırasında özenle ve titizlikle ele alınması gerektiğini duyurmaktadır. Ayrıca, İngilizce öğretmen adaylarının öğretme süreçlerindeki öğretme stilleri tercihleri ile gerçek anlamda profesyonelce sergiledikleri ve eylemleriyle bildirdikleri öğretme stilleri arasındaki ilişki öğretmenlerin atanma süreçlerinde karar alıcılar tarafından dikkate alınmalıdır.
\end{abstract}

Anahtar sözcükler: yabancı bir dil olarak İngilizce öğretimi; öğretme stilleri; Grasha'nın öğretme stili

\section{AUTHOR BIODATA}

Ayfer SU BERGIL is an Assistant Professor Doctor in Amasya University, Faculty of Education, Department of Foreign Language Education, Division of English Language Teaching. She got the PhD degree from Hacettepe University, The Graduate School of Educational Sciences, Division of English Language Teaching in July, 2015; the MA degree from Tokat Gaziosmanpaşa University, The Graduate School of Educational Sciences, Department of Curriculum Development in 2010; BA degree from Gazi University, Faculty of Education, Department of Foreign Language Education, Division of English Language Teaching in 2004. Methodologies of English Language Teaching, curriculum design, teacher education and development are among the fields of her interest.

Ayşegül ERÇEVIK is an instructor in Amasya University, Faculty of Education, Department of Educational Sciences, Division of Guidance and Psychological Counseling. She got the PhD degree from Istanbul UniversityCerrahpaşa, Institute of Graduate Studies, Department of Educational Sciences, Division of Psychological Services in Education in November, 2018; the MA degree from Istanbul University, The Institution of Educational Sciences, Department of Educational Sciences, Division of Psychological Services in Education in 2014; BA degree from Istanbul University, Hasan Ali Yücel Faculty of Education, Division of Guidance and Psychological Counseling in 2010. Methodologies of Psychological Counseling, Psychological Counselor Education, Cognitive Behavioral Therapies, Systemic Family Therapy and adolescence development are among the fields of her interest. 